\title{
Real Estate MSc Curriculum in the New Era of Artificial Intelligence
}

\author{
István Hajnal
}

Budapest University of Technology and Economics, Budapest, Hungary

\begin{abstract}
In Real Estate industry a new era is approaching: Artificial Intelligence (Al) will re-design the map of the whole industry. As the real estate agency processes were moved to electronic platforms, and Al has significant role in brokerage and valuation, other Real Estate disciplines also will change dramatically, as Facility Management, Real Estate Development, Project Management and other related subjects. In this new upcoming era the academic education should accommodate the new approach and the Al-driven processes. In the paper, the Author overview those up-to-date changes and suggest a comprehensive curriculum for a Real Estate master-course which incorporates necessary skills and knowledge for the new generation of Real Estate professionals.
\end{abstract}

(c) 2020 The Authors. Published by Budapest University of Technology and Economics \& Diamond Congress Ltd Peer-review under responsibility of the Scientific Committee of the Creative Construction Conference 2020.

Keywords: real estate, education, artificial Intelligence

\section{Introduction}

Artificial Intelligence (Al) will transform the property business in the near future. Recently, this statement has been formulated by numerous people (see the current article of the Forbes magazine [1], the report of the Oxford Future of Real Estate Initiative [2] or the relatively older publication [3]); however, the expected impact of the COVID-19 pandemic will undoubtedly further accelerate this process. For that matter, some changes are well underway: residential property agencies have already shifted to electronic platforms and retail sales are increasingly supported - and in fact, replaced - by statistical hedonic models. In the field of facility management, however, smart buildings with intelligent building control at their heart are already commonplace. In the construction industry, increasingly more efforts are being invested in artificial process optimisation and robotics. These changes and others are transforming the real estate industry almost from one day to the next. Higher education must teach these changes to future professionals; moreover, prepare them, the new generation, for controlling such changes and overcoming new challenges. This paper attempts to introduce new paradigms in the context of the standard framework of real estate education.

Its first chapter reviews the literature on real estate education and analyzes the curricula of leading real estate courses. The second chapter details the Al-dominated market changes mentioned in the introduction. Finally, the author uses the last chapter to recommend modifications to the traditional framework curriculum.

\section{Review of the relevant literature}

The modernisation of education in general, including university education, the introduction of new technologies and the establishment of opportunities for self-study training and mastering varied skills [4] have been objectives for a long time. Although the education technology and methodology have been widely available, all over the world, university-level real estate education has only partly followed these general objectives. The scope of university-level real-estate education is defined by three fundamental 
schools: the "surveying" approach of the United Kingdom and the Commonwealth countries, the "investment and financing" approach of the USA and finally, the European school, which approaches the discipline of real estate in an interdisciplinary context [5]. Real estate education must adhere to the international trend of globalisation of the real property market, meaning that the methods, procedures, and process participants are the same on said market [6]. The education trends have a notable, decadelong past, just as the programmes of educational institutes. These programmes are quite inert as they were incapable of renewal even after the major real estate crisis of $2008[7,8,9]$. Another issue is that the educational institutes fail to adjust the learning content to industry requirements and a single common corpus, rather choosing to develop it on the available knowledge of teachers [10]. Although the courses have set the goal of meeting industry requirements and training competent professionals, employer feedback shows that this goal is only partly achieved [11]. According to the survey of the courses accredited by the RICS (Royal Institution of Chartered Surveyors), employers expectations focus on knowledge in the following 5 fields:

- Property valuation,

- Property law,

- Landlord and tenant law,

- Internship and ethics,

- Client management.

Although employers do not necessarily look to the future when defining required knowledge, a 2013 survey showed that IT skills were regarded as least necessary among the content taught to real estate professionals [12].

In their 2004 article [10], Galluppo and Worzolla specify the common learning content of real estate higher education (MSc programmes) based on a widespread survey. They divide this learning content into the following three groups.

- Basic courses: Housing financing and housing policies; Real estate law; Ethics and public politics; Commercial real estate financing and investments; Urban and rural real estate development; Real estate valuation.

- Special courses: Urban land economics; Commercial real estate markets; Strategic real estate asset management.

- Cornerstone courses: Negotiation and ethics in the real estate industry; Feasibility study.

Inviting industry speakers, discussing case studies, on-site and company presentations are integral parts of educational programmes [13]. Course content is, of course, also greatly determined by the regulatory environments of countries as well as the authorisation standards of the property industry [14].

Currently, no aggregate data is publicly available on the number of open real estate higher education courses; given that the current RICS list of accredited courses has 394 items ${ }^{3}$, however, the number of courses could be over 1,000 globally. We have checked the content of some outstanding courses (based on the ranking of the "best-masters" website ${ }^{4}$ ) to measure the extent of the paradigm shift related to artificial intelligence. Only one of the top 10 real estate higher education courses with publicly accessible programmes had a relevant course unit: "Real Estate Technology and Innovation", an elective course unit, of the Cornell Baker Program in Real Estate ${ }^{5}$.

We have also reviewed the offer of European higher education programmes in 2020 based on the list of "KEYSTONE Academic Solutions"6, which lists a total of 50 courses in English language, including MSc, MBA,

\footnotetext{
${ }^{3}$ http://www.ricscourses.org/Course/\#Level=Postgraduate/, accessed on 09.04.2020

${ }^{4} \mathrm{https} / / /$ www.best-masters.com/ranking-master-real-estate-management-construction.html, accessed on 09.04.2020.

${ }^{5}$ https://baker.realestate.cornell.edu/programs/concentrations/

${ }^{6}$ https://www.masterstudies.com/Real-Estate/ 
and MA courses. Among the fifty courses, we have found only one, at the ESCP Business School ${ }^{7}$, in which "Real Estate Technology and Innovation" is a complete unit (including modules on Proptech, BigData, SmartCities and real estate software development). The other 49 courses do not include Al or any of its aspects in its programme at all.

The analysis of available courses outlined above also demonstrates that leading real estate courses in higher education still barely touch upon the relationship between Al and the real estate industry.

\section{Fields that will be driven by Artificial Intelligence}

As mentioned in the Introduction, Al is already present in many fields of the real estate industry. The following non-exhaustive list looks at the key fields in which artificial intelligence is already part of everyday business. We relied on the RICS "The World Built Environment Forum" online professional forum in identifying the topics (available at: https://www.rics.org/ssa/wbef/).

Property valuation The most highly-regulated and well-defined real estate discipline. The spread of socalled non-traditional methods has been characteristic of the development of property valuation in the past decade. These methods include hedonic valuation, the use of nervous system networks, contingent valuation or the introduction of fuzzy logic in appraisal [15]. The methodologies, which are often collectively referred to as "mass appraisal", are based on the systematic and automatic analysis of large databases, supported with self-learning models.

Real estate brokerage The residential real estate market is the field that shows the most spectacular breakthrough of Al. This segment of the real estate market has essentially moved to the virtual reality, and the different sites increasingly replace the job of real estate agents by organising, filtering, and presenting the supply in various ways. With the help of artificial intelligence, real estate sites can also provide counselling: they prioritise buyer criteria as required, analyse the relation between an individual offer and the market and give advice on the purchase price based on the varied methods of mass appraisal. The pioneer in this field was the ZILLOW company [16], but a growing number of local sites are also catching up with this trend.

Building operation New commercial buildings are designed almost exclusively with BIM models. BIM is a three-dimensional design tool; during operation, however, the building changes with time-in terms of layouts as well as individual built-in elements. Some authors refer to this change in time as the fourth dimension of BIM, while the " $5^{\text {th }}$ dimension" includes operational parameters (e.g. maintenance data or financial aspects) [17]. Building operation systems based on such models, known as CAFM systems, use enormous datasets as well as integrated "smart technologies" and the input data of automated building management systems (BMS). This enormous and continuously changing database underlies the operationoptimisation of intelligent subsystems such as the energy management function or the smart parking-lot allocation function. Smart buildings - which are not futuristic anymore and automatically ensure an optimum balance between sustainability parameters and user needs - are the next step in this process.

Urbanism "Smart cities" with their autonomous, intelligent, and closely connected systems such as sustainability, public utilities networks, public transport, energy management, and community communication are just a step away from smart buildings. Although there is no single definition for "smart cities" [18] and the entire theoretical concept still does not function in practice, there are some examples and subsystems that show the unavoidable development trend (see, for example, the results of Aspern, an experimental neighbourhood in Austria ${ }^{8}$ ).

In a broader sense, the real estate business (or real estate industry) also includes the construction industry. Although lagging considerably behind other industries, the appearance of robots at construction sites and in building operations is only a matter of time. Moreover, intelligent decision-support systems, including

\footnotetext{
${ }^{7}$ https://www.escpeurope.eu/programmes/specialised-masters-MScs/MSc-in-real-estate?utm_source=keystone\%20masterstudies \&utm_campaign=Megapriority

${ }^{8}$ https://www.aspern-seestadt.at/en/business_hub/innovation_quality/urban_lab 
construction process-optimisation solutions and self-learning project management algorithms are already unavoidable in the construction industry. This transformation of the construction industry is one of the main topics of the Creative Construction Conference series and the keynote speech of Prof. Wen-der Yu at the 2019 conference provides an up-to-date summary of this process [19].

In our opinion, Al will shortly appear in further fields of the real estate business and the real estate industry. Architectural design is one of them. Human creativity is still indispensable in this field; a host of design subtasks - area allocation optimisation according to the function mix or the preparation of detail drawings, product designs - could, however be algorithmised and automated. Layout design is, for example, a process that works with a lot of variables and conditions at the same time. Why not code these variables and rules and use existing examples to teach artificial intelligence to optimally consider usage and cost parameters?

We've seen that $\mathrm{Al}$ is already reshaping the everyday work of real-estate valuators and agencies. The artificial transformation of the real estate market, pricing and timing purchases and sales are just a step away from this. Stock exchange software applications are used on stock markets and real estate investment funds (REITs) are already traded automatically. In itself, this is a market-shaping factor that could be followed by the automated sale and purchase of individual real estates, based on broker firms' databases.

Optimising real estate use is another opportunity for Al. The shared economy has long reached the real estate business, as demonstrated by AirBnB and similar short-term rental services as well as coworking spaces. Apartments and offices, however, are not the only spaces available for short-term use, but partial functions as well. For example, mortgage loan repayment can also be divided between the owner and the lodger. Another example is letting garages in detached houses for temporary or medium-term storage purposes; moreover, some restaurants also rely on private households to extend their kitchen capacities. This also includes the shared economy related to mobility; scooters, bicycles and cars that can be rented even for a couple of minutes have become a part of our everyday lives. The spread of these vehicles will fundamentally affect not only urban transport but also the use of parking places in buildings.

The rapid transformation of the retail sector is also remarkable. $22 \%$ of household purchases have shifted from the streets and malls to e-marketplaces ${ }^{9}$, and this shift is accelerating all over the world. E-commerce in retail transforms not only the background real estate portfolio (logistics centres instead of shop floors, showrooms instead of supermarkets and department stores, etc.) but also the Al systems behind sales by integrating user parameters into the real estate utilisation process.

We mustn't fail to mention the dire and direct consequences of the protective measures against the Covid19 pandemic. Working from home is now a reality in the broadest sense all over the world; in most cases, remote employees are only connected by electronics and logistics (home deliveries and courier services). This experience is expected to transform, expand or end entire industries.

Naturally, Al is based on continuously expanding electronic databases as well as data and metadata that are available on the world wide web. The above-listed fields of the real estate industry are typical examples of applying BIG DATA. In fields with existing or possible large databases, the growing mathematical and increasingly available calculation toolset of data analysis will transform previous practices in a matter of minutes.

It is indisputable that the emergence of $\mathrm{Al}$ in the real estate industry will transform professional rules and activities; this, however, is only possible with a redesigned knowledge base. Therefore, our opinion is that the content of real estate education must be renewed. 


\section{Proposal for a new framework for real estate education}

Azuso and Gibler attempted to renew the framework of real estate education with the CIDO method in 2015 [20]. We feel that the above-detailed major changes in the real estate business require that training contents be rebuilt from scratch. The following is an attempt to do so.

We propose two fundamental methods for organising the relevant knowledge. The first method is the real estate life cycle, an organising principle of all real estate-related activities. Main cycle elements include analysis, planning, execution, marketing and operation (the last two can be listed concurrently as well). The other classification method is according to related disciplines. The real estate discipline is commonly considered a combination of engineering, economic, and legal disciplines; management disciplines must, however, undoubtedly be added to this trio [21]. This review has also clarified that IT is another relevant discipline; the original trio is, therefore, to be transformed into a quintet. The matrix of Figure 1 below shows the combination of the two organising principles.

\section{Real Estate Cycle and disciplines}

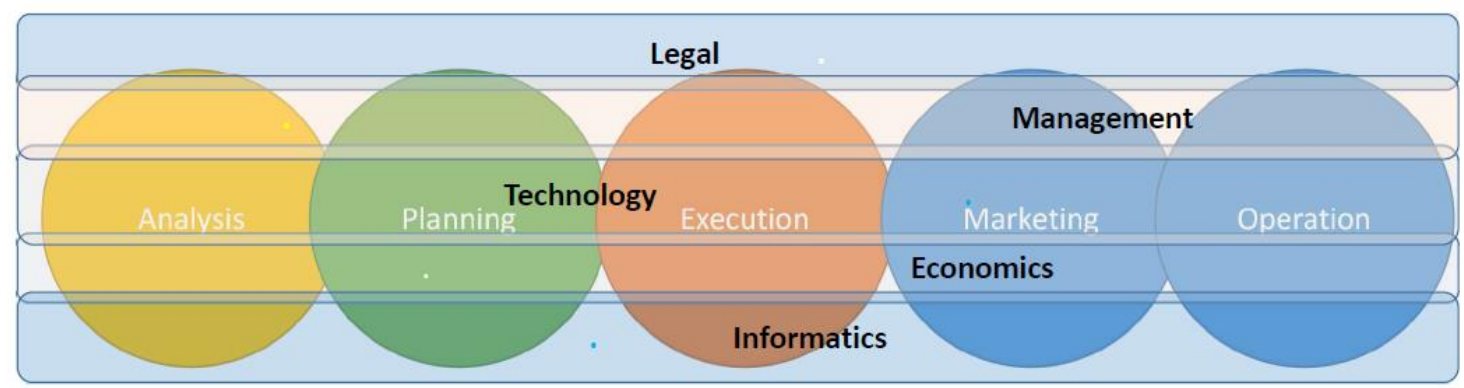

Figure 1: A combined matrix of the real estate market cycle and related disciplines

The main courses could be based on this system. Based on the 5-by-5 table, we propose the following 25 courses and topics as main knowledge units for higher education courses in real estate. (Table 1).

Table 1: Proposed education topics

\begin{tabular}{|c|c|c|c|c|c|c|}
\hline & & \multicolumn{5}{|c|}{ RE Cycle process } \\
\hline & & Analysis & Planning & Execution & Marketing & Operation \\
\hline & Legal & RE Law & Building Law & Civil Law & Economic Law & Urbanism \\
\hline i & Management & Negotiation & $\begin{array}{c}\text { Human Resource } \\
\text { Management }\end{array}$ & Project Management & RE Marketing & $\begin{array}{c}\text { Organisational } \\
\text { Behavior }\end{array}$ \\
\hline $\begin{array}{l}c \\
\mathrm{i}\end{array}$ & Technology & Valuation & Development & $\begin{array}{c}\text { Building technologies } \\
\text { and structures }\end{array}$ & Building Diagnostics & Energetics \\
\hline p & Economics & RE Market & Finance & Controlling & Business Economics & Accounting \\
\hline $\begin{array}{l}\mathrm{n} \\
\mathrm{e}\end{array}$ & Informatics & Statistics & BIM & $\begin{array}{c}\text { Low voltage systems } \\
\& \text { BIS }\end{array}$ & BIG DATA & $\mathrm{Al}$ \\
\hline
\end{tabular}

Courses could be scheduled either according to the real estate cycle or deviating from it; the conceptual structure of Figure 1 should, however, be explained to the students when introducing each module. The topics summarised in Table 1 are based on one another and are related both horizontally and vertically. We also wish to note that urbanism, which is another related discipline, could have been included in any of the rows or columns of the table; it is, therefore, highlighted with a different background colour. Obviously, it is not possible to present, teach and assess the understanding of the entire knowledge base of each and every related discipline in a real estate course, yet this is not the goal. Moreover, the topics of Table 1 do not necessarily have an identical weight or credit scores. 
The present study only focuses on a handful of knowledge units that are significant in terms of our topic, Al. As for the legal aspects, we must note that the new virtual world now taking shape raises a host of legal issues (personality rights, prompt contracts, intellectual property rights) that real estate lawyers are not prepared for. The knowledge of this field is also continuously taking shape and expanding. In management, the development of human resources and enhancing creative energies are becoming increasingly important. The traditional real estate market approach rather prefers regulated processes and hierarchy; however, in the age of Al, when background processes are performed by computers, educational courses must prepare students for creative management as well as giving them thorough insights into the background processes and intermediary organisations. The technical knowledge base is infinite-just like that of the other disciplines. For real estate market players, the most important new requirement is sustainability, which appears in and interlaces all activities; therefore, it does not require a separate block. At the same time, building energy plays a special role in sustainable operations; a separate course should, therefore, deal with this field, despite the fact that it was previously neglected in real estate courses. Understanding financial and controlling processes and the ability to make creative decisions based on the information provided by artificial intelligence are more important for students than ever before. Teaching mathematical statistics in the IT block is also to ensure that students understand the functions, capabilities and limits of the "machine". As shown above, BIM and the various building model dimensions appear in the entire real estate lifecycle and future real estate professionals should be able to interpret and manage these models. The weak current network is the "nervous system" and the building management system (BMS) is the "brain" of our buildings. Professionals should understand these complex systems just as traditional building structures. The storage and organising of large datasets (BIG DATA) and obtaining meaningful and efficient information from data are further knowledge and skills that take real estate professionals closer to understanding and perhaps coding Al. We must know how artificial intelligence can best serve human and, more specifically, real estate needs, when set free.

\section{Summary}

The changing and reshaping real estate industry requires new skills and knowledge. Previous course literature and current practices have not yet adapted to these new requirements. The learning content that has been developed over decades and which is now the backbone of professional knowledge cannot and should not be discarded. It should be further developed and extended to prepare real estate market players for the direct challenges of co-existing with artificial intelligence.

\section{References}

[1] How Will Artificial Intelligence Change The Commercial Real Estate Industry?, https://www.forbes.com/sites/forbesrealestatecouncil/2020/02/21/how-will-artificial-intelligence-change-the-commercial-real-estateindustry/\#72f8523424f8, accessed 09.04.2020

[2] Saïd Business School (2020), PROPTECH 2020: THE FUTURE OF REAL ESTATE, Oxford Future of Real Estate Initiative, https://www.sbs.ox.ac.uk/sites/default/files/2020-02/proptech2020.pdf, accessed 2020. 04.10.

[3] Shi-Ming, Y. (2001). New paradigms in real estate education. Pacific Rim Property Research Journal, 7(2), 79-88. https://doi.org/10.1108/pm.2001.11319eac.003

[4] Whelan, R. (1998). Future directions of research and development in European educational technologies. Planning for Progress, Partnership and Profit. Proceedings EdTech'98. https://doi.org/10.4337/9780857932167.00029

[5] Schulte, K. W., Schulte-Daxbök, G., Holzmann, C., \& Wiffler, M. (2005, April). Internationalisation of real estate education. In ERES Conference: Dublin, Ireland. https://doi.org/10.15396/eres2005_310

[6] Black, R., \& Carn, N. (1998). International Real Estate And The University Curriculum. In ARES Conference: Monterey, United States.

[7] Saginor, J., Weinstein, M., \& Worzala, E. (2014). Graduate real estate education: a survey of programs after the great recession. Journal of Real Estate Practice and Education, 17(2), 87-109.

[8] D'Arcy, É., \& Taltavull, P. (2009). Real estate education in Europe: some perspectives on a decade of rapid change. Journal of European Real Estate Research. https://doi.org/10.1108/17539260910959563

[9] Hajnal, I., \& Rostás, Z. (2013). Architect Education in the light of the real estate crisis. Miklós Hajdu, Mirosław J. Skibniewski. In Creative Construction Conference 2013 (pp. 2013).

[10] Galuppo, L., \& Worzala, E. (2004). A Study into the Important Elements of a Masters Degree in Real Estate. Journal of Real Estate Practice and Education, 7(1), 25-42.

[11] Poon, J., Hoxley, M., \& Fuchs, W. (2011). Real estate education: an investigation of multiple stakeholders. Property Management, 29(5), 468-487. https://doi.org/10.1108/02637471111178146

[12] Chikafalimani, S. H. P. (2013). Curriculum Guideline for Masters Real Estate Education in South Africa. Academic Journal of Interdisciplinary Studies. https://doi.org/10.5901/ajis.2013.v2n3p397

[13] Chambers, L., Holm, J., \& Worzala, E. (2009). Graduate Real Estate Education: Integrating the Industry. International Journal of Property Sciences, 2(1), 1-18. https://doi.org/10.22452/ijps.vol2no1.1 
Proceedings of the Creative Construction e-Conference (2020) 035

Available online at e-2020.creative-construction-conference.com/proceedings/

[14] Marona, B., \& Głuszak, M. (2014). The Ties that Bind? Real Estate Education in Europe and Regulatory Framework in Poland. The New Educational Review, 35(1), 187-201.

[15] Zurada, J. M., Levitan, A. S., \& Guan, J. (2011). Non-Conventional Approaches To Property Value Assessment. Journal of Applied Business Research (JABR), 22(3). https://doi.org/10.19030/jabr.v22i3.1421

[16] Humphries, S. \& Rascoff, S. (2017). ZillowSztorik - Lakáspiaci tények és tévhitek - Hogyan müködik ma valójában az ingatlanpiac?, [Zillow stories - Residential market facts and misinterpretations - How real estate market works?] A4C Books, Budapest

[17] Charef, R., Alaka, H., \& Emmitt, S. (2018). Beyond the third dimension of BIM: A systematic review of literature and assessment of professional views. Journal of Building Engineering, 19, 242-257. https://doi.org/10.1016/j.jobe.2018.04.028

[18] Neirotti, P., De Marco, A., Cagliano, A. C., Mangano, G., \& Scorrano, F. (2014). Current trends in Smart City initiatives: Some stylised facts. Cities, 38, 25-36. https://doi.org/10.1016/j.cities.2013.12.010

[19] Yu, Wen-der (2019). How Artificial Intelligence Will Shape the Future of Construction. https://2019.creative-constructionconference.com/wp-content/uploads/2019/06/CCC2019 FPBoA.pdf accessed 11.04.2020.

[20] Azasu, S., \& Gibler, K. (2014). INTEGRATING STAKEHOLDER VIEWS INTO REAL ESTATE CURRICULA - ADAPTING THE CDIO APPROACH TO A SOUTH AFRICAN REAL ESTATE PROGRAM. Urban Real Estate Markets: a Catalyst for Economic Growth and Development - the 14th African Real Estate Society Conference. https://doi.org/10.15396/afres2014_114

[21] Hajnal, I. (2014). Teaching facility management. In conference proceedings of People, Buildings and Environment 2014, an international scientific conference, Kroměřǐž, Czech Republic, pp. 724-731. 